\title{
Lipid and Protein Oxidation in Charqui Meat and Jerked Beef
}

\author{
Marta A. A. Souza ${ }^{1}$, Jesui V. Visentainer ${ }^{2}$, Rafael H. Carvalho ${ }^{1}$, Fabianne Garcia ${ }^{1}$, Elza I. \\ Ida $^{1}$, Massami Shimokomaki ${ }^{1,3,4^{*}}$ \\ ${ }^{I}$ Programa de Pós Graduação em Ciência dos Alimentos; Departamento de Ciência e Tecnologia de Alimentos; \\ Universidade Estadual de Londrina; Londrina - PR - Brasil. ${ }^{2}$ Departamento de Química; Universidade Estadual de \\ Maringá; Maringá - PR - Brasil. ${ }^{3}$ Programa de Ciência Animal; Universidade Estadual de Londrina; C.P.: 6001; \\ 86051-980; Londrina - PR - Brasil. ${ }^{4}$ Universidade Tecnológica Federal do Paraná; Campus de Londrina; Londrina \\ - PR - Brasil
}

\begin{abstract}
In this study, the changes in the lipid (Lox) and protein oxidation (Pox) were measured quantitatively by TBARS and carbonyl methods, respectively, throughout the salting and drying steps of charqui meat (CH) and jerked beef (JB) preparation and their storage up to 60 days. The experiment was carried out on $C H$ samples treated with brine $(20.0 \%)$ and JB with same brine solution added with sodium nitrite $(0.02 \%)$. After 60 days of storage, the carbonyl substances in $\mathrm{CH}$ were $2.77 \mathrm{nmol} \mathrm{mg}^{-1}$ while in the JB samples, there was $61.0 \%$ oxidation inhibition. The TBARS determination revealed a Lox inhibition by approximately 5-fold in the latter samples. These results indicated that in the metmyoglobin molecule, the nitrite kept the Fe in the Fe $e^{2+}$ state in JB samples whereas in $\mathrm{CH}$, the Fe was oxidized to $\mathrm{Fe}^{3+}$, which catalyzed the oxidation reactions more efficiently, leading to the higher development of Lox and Pox.
\end{abstract}

Key words: protein oxidation, charqui, jerked beef

\section{INTRODUCTION}

Lipid (Lox) and Protein oxidations (Pox) are the resultant of an imbalance of prooxidant/antioxidant contents. Therefore, it is necessary to reach the oxidation homeostasis conditions in the food system in order to avoid them. By its composition and because of the harsh conditions to produce Charqui, this popular salted meat product seems to be excellent model to examine further these oxidative reactions. According to the Brazilian legislation, Charqui meat $(\mathrm{CH})$ should contain $40-50 \%$ moisture and $10-20 \%$ salt (Brasil 1962) and 0.75 is the final value of its water activity, ranking it as an intermediate moisture meat product (Torres et al. 1994; Shimokomaki et al. 1998). On the other hand, a derivative cured meat product, commercially known as Jerked beef (JB) has officially been defined by the Brazilian legislation as having maximum 55\% moisture, $50 \mathrm{ppm}$ sodium nitrite, $18 \%$ salt a final $\mathrm{a}_{\mathrm{w}}$ value of 0.78 and should be vacuum packed (Brasil 2000). Thus, technologically $\mathrm{JB}$ is an improvement from $\mathrm{CH}$ (Shimokomaki et al. 2003). Both products are the results of the so-called hurdle technology application in their processing (Leistner 1987; Torres et al. 1994). As recently described, salt, sodium nitrite, dehydration and packaging are hurdles sequentially applied to inhibit the

*Author for correspondence: mshimo@uel.br 
microorganism's development (Shimokomaki et al. 1998). There is a selection for the halophylic bacteria in the particular fermentative microorganisms as demonstrated by Pinto et al. (2002). The conditions of $\mathrm{CH}$ preparation have been discussed elsewhere (Shimokomaki et al. 1998). The addition of $\mathrm{NaCl}$ in the meat preparation under these conditions changes the meat functional properties, in particular alter the iron state from ferrous $\left(\mathrm{Fe}^{2+}\right)$ of oxymyoglobin to ferric $\left(\mathrm{Fe}^{3+}\right)$ of metmyoglobin through the Fenton reactions, thus becoming higher meat pro-oxidant (Youssef et al. 2003). Under these conditions, $\mathrm{NaCl}$ is capable of enhancing the production of ROS catalyzing, in cascade reactions, the meat lipids and protein oxidation measured by the TBARS and carbonyl substances, respectively (Youssef et al. 2003; Montero et al. 2005).

There are several reports on the application of antioxidants in order to minimize these undesirable reactions in the food systems (Park et al. 2006; Ooizumi and Xiong 2006; 2008; Lund et al. 2007). Cured salts are essential ingredients for meat processing and nitrite plays a strong antioxidant role as originally reported by Pearson et al. (1977). Nitrite also acts as lipids antioxidant in the mechanical deboning of chicken meat (Trindade et al. 2008) and also in $\mathrm{CH}$ and JB (Youssef et al. 2003; 2011). Thus, the objective of this work was to determine quantitatively the amount of lipids and proteins oxidations through the TBARS and carbonyl determinations, respectively. The inhibition of these oxidations by sodium nitrite was evaluated throughout the charqui meat and jerked beef processing and storage up to 60 days.

\section{MATERIALS AND METHODS}

\section{Meat samples}

Zebu (Bos indicus) meat samples were taken from Vastus lateralis $m$. and kindly donated by a commercial charqui $(n=6)$ and jerked beef $(n=6)$ industry located in the Londrina city, Parana state.

\section{Charqui meat and Jerked beef processing}

The $\mathrm{CH}$ processing steps followed the techniques described elsewhere (Shimokomaki et al. 1998). Essentially, brine of $20 \% \mathrm{NaCl}$ (w/v) was automatically injected in Vastus lateralis $\mathrm{m}$. followed by dry salting on a concrete floor for five days. Subsequently, after washing to remove the excess of meat surface salt, samples were submitted to drying directly in the sun and wind, hung upon stainless steel rails under a maximum temperature of $40-45^{\circ} \mathrm{C}$ in the summer. The dried and salted products were finally vacuum packed. The JB followed similar processing, except that sodium nitrite $(0.02 \%)$ was added to the brine for the injection salting step.

\section{Sample preparation for analysis}

Samples of $16 \mathrm{~g}$ in duplicate were dialyzed against the distilled water in order to remove the salt residue and freeze dried for further analysis.

\section{Metmyoglobin determination (MMb)}

Five grams of ground desalted and freeze dried $\mathrm{CH}$ and $\mathrm{JB}$ were solubilized in $25 \mathrm{~mL}$ of phosphate buffer (pH 6.8) according to Krzywicki (1982). This solution was treated in a homogenizer (Turrax) at 13,500 rpm for $10 \mathrm{~s}$ and left for $1 \mathrm{~h}$. The mixture was centrifuged at $5,000 \mathrm{~g}$ and $4^{\circ} \mathrm{C}$ for $30 \mathrm{~min}$. The supernatant was filtered in a Whatman \#1 paper. The absorbance of the filtrate was read in a spectrophotometer at 525, 572 and 700nm and the $\mathrm{MMb}$ concentration was calculated using equation 1:

$\mathrm{MMb}=\left\{1.395-\left[\left(\mathrm{A}_{572}-\mathrm{A}_{700}\right) /\left(\mathrm{A}_{525}-\mathrm{A}_{700}\right)\right]\right\} \times 100$ (equation 1)

$\mathrm{A}_{525}=$ absorbance at $525 \mathrm{~nm}$ of the supernatant $\mathrm{A}_{572}=$ absorbance at $572 \mathrm{~nm}$ of the supernatant $\mathrm{A}_{700}=$ absorbance at $700 \mathrm{~nm}$ of the supernatant.

Metmyoglobin was evaluated in triplicate and expressed in percent $(\%)$.

\section{Lipid oxidation determination}

Lipid oxidation was evaluated in triplicate following Tarladgis et al. (1964) method as described in Soares et al. (2004). The results were expressed in mg TBARS $\mathrm{kg}^{-1}$ of the sample.

\section{Protein oxidation determination}

Protein oxidation in triplicate was determined by the derivatization with 2,4-dinitrophenylhydrazine as described in Fagan et al. (1999). Briefly, 3.0g of freeze dried samples in triplicate were solubilized in $25.0 \mathrm{~mL}$ of buffer ( $\mathrm{pH} 7.4$ ), containing $\mathrm{Na}_{4} \mathrm{P}_{2} \mathrm{O}_{7}$ $(2.0 \mathrm{mM})$, Tris-maleate $(10 \mathrm{mM}), \mathrm{KCl}(100 \mathrm{mM})$, $\mathrm{MgCl}_{2}(2.0 \mathrm{mM})$ and EGTA $(2.0 \mathrm{mM})$. The mixture was homogenized in Turrax twice at $8,000 \mathrm{~g}$ in an ice bath and centrifuged at $800 \mathrm{~g}$ and $4^{\circ} \mathrm{C}$ for $20 \mathrm{~min}$. The supernatant was filtered through the cheesecloth and was further centrifuged at $38,720 \mathrm{~g}$ and $4^{\circ} \mathrm{C}$ for $1 \mathrm{~h}$. After filtration through the 
cheesecloth, an aliquot of $1.0 \mathrm{~mL}$ was treated with $5.0 \mathrm{~mL}$ the $\mathrm{HCl} /$ acetone $(3: 1)$ and centrifuge twice for $20 \mathrm{~min}$ at $4^{\circ} \mathrm{C}$. The pellet was treated with $5.0 \mathrm{ml}$ of $10 \%$ TCA. After centrifugation at $800 \mathrm{~g}$ and $4{ }^{\circ} \mathrm{C}$ for $20 \mathrm{~min}$, finally, the pellet was dissolved in $1.0 \mathrm{~mL}$ buffer as described with $1.0 \mathrm{ml}$ of DNPH solution. Blanks were prepared by adding $1.0 \mathrm{~mL}$ buffer and $1.0 \mathrm{~mL} 2.0 \mathrm{M} \mathrm{HCl}$ to a separate aliquot of albumin solution, which was left under agitation in darkness at $4^{\circ} \mathrm{C}$ for $60 \mathrm{~min}$. Trichloroacetic acid was added to a final concentration of $7 \%$, and the samples were centrifuged at $11,000 \mathrm{~g}$ for $20 \mathrm{~min}$ and the pellet was treated three times with ethanol/ethyl acetate (1:1) in $10 \mathrm{mM} \mathrm{HCl}$ and centrifuged at $800 \mathrm{~g}$ and $4^{\circ} \mathrm{C}$ for $20 \mathrm{~min}$. The pellet was solubilized with guanidine (6.0M) in phosphate buffer $(\mathrm{pH} 2.3)$ and after centrifugation, the carbonyl concentration was read at $380 \mathrm{~nm}$ and plotted in an albumin solution standard curve. The carbonyl content was determined spectrophotometrically at $380 \mathrm{~nm}$, using a molar absorbance coefficient of $22,000^{\mathrm{M}-1} \mathrm{~cm}^{-1}$.

\section{Statistical Analysis}

All results were analyzed using the program STATISTICA for Windows version 5.0 (StatSoft, 1995). The effect of antioxidant application was evaluated through the ANOVA and the Tukey test $(5 \%)$ was used to assess the significance of difference.

\section{RESULTS}

\section{Metmyoglobin content (MMb)}

Table 1 shows the MMb amount found throughout the processing and storage of the $\mathrm{CH}$ and JB. The amount of $\mathrm{MMb}$ in the $\mathrm{CH}$ was approximately 3fold in relation to JB samples, irrespective of storage time $(\mathrm{p}<0.05)$.

Table 1 - Metmyoglobin level (\%) found in charqui meat and in jerked beef throughout processing and storage up to 60 days.

\begin{tabular}{ccc}
\hline Days & Charqui meat & Jerked beef \\
\hline 1 (brining) & $20.27^{\mathrm{a}} \pm 1.43$ & $5.41^{\mathrm{b}} \pm 0.32$ \\
8 (after drying) & $68.50^{\mathrm{c}} \pm 2.11$ & $20.46^{\mathrm{d}} \pm 1.76$ \\
30 (storage) & $72.05^{\mathrm{e}} \pm 2.32$ & $25.56^{\mathrm{f}} \pm 1.1$ \\
60 (storage) & $71.86^{\mathrm{g}} \pm 2.05$ & $25.84^{\mathrm{h}} \pm 1.4$ \\
\hline
\end{tabular}

Triplicate mean with different letters on the same line differs significantly $(\mathrm{p}<0.05)$ by the Tukey test.

\section{Lipid oxidation}

Table 2 shows the TBARS values found in the $\mathrm{CH}$ and in JB samples. At first day of processing, the TBARS results did not show any difference $(\mathrm{p}<0.05)$. However, from the $8^{\text {th }}$ days of storage, the TBARS values increased gradually, reaching its maximum at the $60^{\text {th }}$ day of the storage.

Table 2 - Levels of TBARS ( $\mathrm{mg} \mathrm{kg}^{-1}$ ) found in charqui meat and jerked beef throughout processing and storage up to 60 days.

\begin{tabular}{ccc}
\hline Days & Charqui meat & Jerked beef \\
\hline 1 & $0.057^{\mathrm{a}} \pm 0.002$ & $0.023^{\mathrm{a}} \pm 0.002$ \\
8 & $0.11^{\mathrm{b}} \pm 0.009$ & $0.04^{\mathrm{c}} \pm 0.003$ \\
30 & $0.11^{\mathrm{d}} \pm 0.008$ & $0.045^{\mathrm{e}} \pm 0.002$ \\
60 & $0.25^{\mathrm{f}} \pm 0.011$ & $0.05^{\mathrm{g}} \pm 0.003$ \\
\hline
\end{tabular}

Triplicate mean with different letters on the same line differs significantly $(\mathrm{p}<0.05)$ by the Tukey test.

\section{Protein oxidation}

Table 3 showed that the carbonyl substances found in both the samples were not different on the $1^{\text {st }}$ and $8^{\text {th }}$ days of processing. However, there was a gradual increase during the storage, reaching a maximum at 0 days of the storage. Moreover, from the $30^{\text {th }}$ day, the levels of carbonyl substances were significantly higher in the $\mathrm{CH}(\mathrm{p}<0.05)$ compared to JB. 
Table 3 - Levels of carbonyl substances $\left(\mathrm{nmol} \mathrm{mg}{ }^{-1}\right.$ ) of charqui meat and jerked beef stored up to 60 days.

\begin{tabular}{ccc}
\hline Days & Charqui meat & Jerked beef \\
\hline 1 & $0.32^{\mathrm{a}} \pm 0.04$ & $0.28^{\mathrm{a}} \pm 0.03$ \\
8 & $0.70^{\mathrm{b}} \pm 0.05$ & $0.54^{\mathrm{b}} \pm 0.06$ \\
30 & $1.07^{\mathrm{c}} \pm 0.08$ & $0.76^{\mathrm{d}} \pm 0.07$ \\
60 & $2.77^{\mathrm{e}} \pm 0.12$ & $1.08^{\mathrm{f}} \pm 0.08$ \\
\hline
\end{tabular}

Triplicate mean with different letters on the same line differs significantly $(\mathrm{p}<0.05)$ by the Tukey test.

\section{DISCUSSION}

These results corroborated clearly that under the harsh conditions of the $\mathrm{CH}$ and $\mathrm{JB}$ processing, the oxidative reactions occurred not only for the Lox as reported previously (Torres et al. 1989; Youssef et al. 2003) but also for the Pox.

However, there was difference in intensity pattern during the storage for these reactions as Lox appeared to occur more intensely after eight days of processing (Table 2) as previously reported (Youssef et al. 2003) increasing approx. 5-fold at the $60^{\text {th }}$ day of storage. Pox started occurring after the $30^{\text {th }}$ day after initiation of salting (Table 3), reaching maximum value at the $60^{\text {th }}$ day of storage. This study showed that the pigment myoglobin suffered changes under the high salt concentration. The MMb amount was approximately 3 -fold in the $\mathrm{CH}$, showing the deleterious role of $\mathrm{NaCl}$ over myoglobin from the start of salting up to 60 days of storage. Nitrite protected this oxidation from occurring in the JB (Table 1). It was clear that from the start to approximately eight days of processing, the ROS components were being synthesized and becoming available for the further oxidation first of lipid and finally of protein. Previously studies have shown that free radicals were formed and hexanal was detected at first days under the salting process (Torres et al. 1988). Therefore, the possibility of Lox development could not be ruled out as further free radicals would be formed enhancing ultimately the Pox reactions. Several authors have reported the existence of direct relationship between the disruption of heme molecule during the heat treatment and the free iron would increase its concentration having as consequence gradual oxidative degradation in the cooked meat (Miller et al. 1994). Estévez et al. (2004; 2005) reported a significant correlation between the concomitant increase of free iron and the TBARS content. The results reported herein also showed that there was a direct relationship between the concentration level of the $\mathrm{MMb}$ and TBARS, suggesting that $\mathrm{Fe}^{3+}$ formation was induced by the oxidative environment promoted by the salting conditions catalyzing ROS synthesis as previously observed (Youssef et al. 2003).

Therefore, the higher availability of the ROS increased the oxidative reactions for both the Lox (Table 2) and Pox (Table 3). The inhibition of both the Lox and Pox in JB was most probably due to the presence of sodium nitrite packed under the vacuum. The present results corroborated the previous observation for the Lox in the JB samples and for the first time for the Pox. At least two possibilities existed to explain the role of nitrite as an oxidation inhibitor in the cured samples. Firstly, it chelated the free $\mathrm{Fe}^{3+}$ formed because of the high salt concentration, and thus, its pro oxidant was inhibited. Secondly, it reacted with the meat pigments, thus forming nitrosylmyoglobin- $\mathrm{Fe}^{2+}$ and enhancing the oxidation, while $\mathrm{CH}$-free nitrite samples would form $\mathrm{MMb}-\mathrm{Fe}^{3+}$, favoring these oxidation reactions. The harsh conditions of the $\mathrm{CH}$ processing under the high concentration of salt and by drying under the sun at $40-45^{\circ} \mathrm{C}$ for several days would denature the myofibrillar proteins (Shimokomaki et al. 1998) and collagen (Biscontini et al. 1996), thus, the gradative protein denaturation was positively correlated with the Lox as reported in dark chicken meat (Jing Li and King 1996).

\section{CONCLUSIONS}

Both, the lipids and proteins oxidations occurred during the salting, drying and storage of the charqui meat and jerked beef. However, there was a time difference in their installation: lipids oxidation being the first to occur and later protein oxidation possibly by the gradual formation of the ROS from the lipid oxidation. The presence of sodium nitrite was capable of partially inhibiting these undesirable reactions throughout the processing and storage of the jerked beef. 


\section{ACKNOWLEDGEMENTS}

Authors are grateful to JFZ Indústrias e Comércio de Alimentos Ltda, Londrina, PR, Brazil, for providing facilities and the meat products samples. This research project was supported by Fundação Araucária/CNPq Pronex (Protocols 09.277 and 17.347) and Fundação Araucária/Finep under the BioAgroPar Program. MAAS was under CAPES/MEC doctoral scholarship, RHC was under $\mathrm{CNPq}$ Scientific Initiation scholarship and JVV, EII and MS are CNPq Research Fellows.

\section{REFERENCES}

Biscontini TMB, Shimokomaki M, Oliveira S.F. Zorn, TMT. An ultrastructural observation on charquis salted and intermediate moisture meat products. Meat Sci. 1996; 43: 351-358.

Brasil. Ministério da Agricultura. Regulamento de Inspeção Industrial e Sanitária de Produtos de Origem Animal. Rio de Janeiro; 1962. p.174.

Brasil. Portaria n. 3, de 17 de Janeiro de 2000. Diário Oficial da União, Brasilia, DF, Seção 1, n. 16, p. 1627.

Estévez, M, Cava, R. Lipid and protein oxidation, release of iron from heme molecule and colour deterioration during refrigerated in liver paté. Meat Sci. 2004; 68: 551-558.

Estévez M, Ventanas S, Cava R. Protein oxidation in frankfurters with increasing levels of added rosemary essential oil: effect of colour and texture deterioration. J. Food Sci. 2005; 70: 427-432.

Fagan, JM, Slezka, BG, Sohar, I. Quantitation of 6oxidative damage to tissue proteins. Int. J. Biochem. Cell Biol. 1999; 31: 751-757.

Jing Li S, King AJ. Lipid oxidation and myosin denaturation in dark chicken meat. J. Agric. Food Chem. 1996; 44: 3080-3084.

Krzywicki, K. The determination of haem pigment in meat. Meat Sci. 1982; 7: 29-32.

Leistner L. Shelf stable product and intermediate moisture foods based on meat. Rockland, L and Beuchat, L. B. (eds.) Water activity theory and application to food, Marcel Dekker Inc., New York, 1987. p.295-328.

Lund MN, Hviid MS, Skibsted LH. The combined effect of antioxidants and modified atmosphere packaging on protein and lipid oxidation in beef patties during chill storage. Meat Sci. 2007; 76: 226233.
Miller DK, Gómez-Basauri JV, Smith VL, Kanner J, Miller DD. Dietary iron in swine rations affects nonheme iron and TBARS in pork skeletal muscles. $J$. Food Sci. 1994; 59: 747-750.

Montero P, Giménez B, Pérez-Mateos M. GomezGuillén MC. Oxidation stability os muscle with quercetin and rosemary during thermal and highpressure gelation. Food Chem., 2005; 93: 17-23.

Oozumi T, Xiong YL. Identification of cross-linking site(s) of myosin heavy chains in oxidatively stressed chicken myofibrils. J. Food Sci. 2006; 71: 196-199.

Ooizumi T. Xiong YL. Hydroxyl radical oxidation destabilizes subfragment-1 but not the rod of myosin in chicken myofibrils. Food Chem. 2008; 106: 661668.

Park D, Xiong YL, Alderton AL. Concentration effects of hydroxyl radical oxidizing systems on biochemical properties of porcine muscle myofibrillar protein. Food Chem. 2006; 101: 1239-1246.

Pearson AM, Love JD, Shorland FB. Warmed-over flavor in meat, poultry and fish. Adv. Food Res. 1977; 23: 1-74.

Pinto MF, Ponzano EHG, Franco BDGM, Shimokomaki M. Charqui meats as fermented meat products: role of bacteria for some sensorial properties development. Meat Sci. 2002; 61: 187-191.

Soares AL, Olivo R, Shimokomaki M, Ida EI. Synergism between dietary vitamin $\mathrm{E}$ and exogenous phytic acid in prevention of warmed over flavor development in chicken Pectoralis major. Braz. Arch. Bio. Technol. 2004; 47: 57-62.

Shimokomaki M, Franco BDGM, Biscontini TM, Pinto MF, Terra NN, Zorn TMT. Charqui meat are hurdle technology meat products. Food Rev. Int. 1998; 14: 339-349.

Shimokomaki M, Yousef EY, Terra NN. Curing. In: Encyclopedia of Food Science and Nutrition, $2^{\text {nd }}$ edition, Academic Press, New York, 2003. p. 17021707.

STATSOFT, Inc., 1995. STATISTIC for Windows (Computer program manual). Tulsa, Oklahoma, USA.

Tarladgis BG, Pearson AM, Dugan LR Jr. Chemistry of the 2-thiobarbituric test for determination of oxidative rancidity in foods II. Formation of the TBAmalonaldehyde complex without acid-heat treatment. J. Food Sci. Agr. 1964; 5: 602-604.

Torres E, Pearson AM, Gray JI, Booren AM, Masami $S$. Effect of salt on oxidative changes in pre- and post-rigor ground beef. Meat Sci. 1988; 23: 151-163.

Torres E, Pearson AM, Gray JI, Ku PK, Shimokomaki, M. Lipid oxidation in charqui (salted and dried beef). Food Chem. 1989; 32: 257-268. 
Torres EAFS, Simokomaki M, Franco BDGM, Landgraf M, Carvalho JBCC, Santos JC. Parameters determining the quality of charqui, an intermediate moisture meat product. Meat Sci. 1994; 38: 229-234.

Trindade MA, Nunes TP, Contreras-Castillo CJ, Felício PE. Estabilidade oxidative e microbiológica em carne de galinha mecanicamente separada e adicionada de antioxidantes durante periodo de armazenamento a $18^{\circ}$ C. Ciênc. Tecnol. Alim. 2008; 28: 160-168.
Youssef EY, Garcia CER, Shimokomaki M. Effect of salt and color and warmed over flavor in charqui meat processing. Braz. Arch. Biol. Technol. 2003; 46: 595-600.

Youssef EY, Rocha Garcia CE, Figueiredo B, Shimokomaki, M. Residual levels of curing salts and its antioxidant effect in Jerked beef. SEMINA:Ciênc. Agrár. 2011; 32: 645-650. 